\title{
Successful mainstream nitritation through NOB inactivation
}

\author{
D. Hausherr ${ }^{\mathrm{a}, *}$, R. Niederdorfer ${ }^{\mathrm{b}}$, H. Bürgmann ${ }^{\mathrm{b}}$, M.F. Lehmann ${ }^{\mathrm{c}}$, P. Magyar ${ }^{\mathrm{c}}$, J. Mohn $^{\mathrm{d}}$, \\ E. Morgenroth ${ }^{\mathrm{a}, \mathrm{e}}$, A. Joss ${ }^{\mathrm{a}}$
}

${ }^{a}$ Eawag, Swiss Federal Institute of Aquatic Science and Technology, Process Engineering Department, 8600 Dübendorf, Switzerland

${ }^{\mathrm{b}}$ Eawag, Swiss Federal Institute of Aquatic Science and Technology, Surface Water Department, 6047 Kastanienbaum, Switzerland

${ }^{\mathrm{c}}$ University of Basel, Aquatic and Isotope Biogeochemistry, Department of Environmental Sciences, 4056 Basel, Switzerland

d Empa, Swiss Federal Institute for Materials Science and Technology, Laboratory for Air Pollution/Environmental Technology, 8600 Dübendorf, Switzerland

e ETH Zürich, Institute of Environmental Engineering, Department of Civil, Environmental and Geomatic Engineering, 8093 Zürich, Switzerland

\section{H I G H L I G H T S}

- Nitritation was stable in municipal wastewater, even at low temperatures $\left(8{ }^{\circ} \mathrm{C}\right)$.

- A one-hour anaerobic phase, after reactor filling, rapidly established nitritation.

- Bottom-feeding was used for a $90 \%$ volume exchange each SBR cycle.

- NOB suppression is driven by NOB inactivation rather than washout.

- Up-scaling of nitritation to an $8 \mathrm{~m}^{3}$ reactor was successful.

\section{A R T I C L E I N F O}

\section{Article history:}

Received 25 October 2021

Received in revised form 24 January 2022

Accepted 26 January 2022

Available online 29 January 2022

Editor: Paola Verlicchi

\section{Keywords}

Municipal wastewater

Nitritation

Anaerobic

Plug flow

NOB inactivation
G R A P H I C A L A B S T R A C T

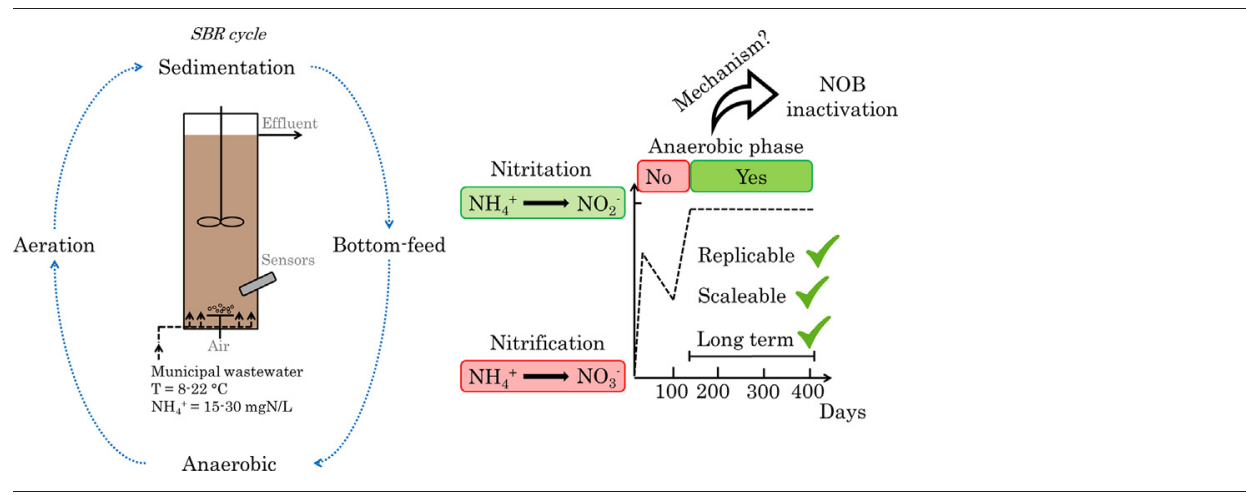

\section{A B S T R A C T}

The development of new wastewater treatment processes can assist in reducing the impact of wastewater treatment on the environment. The recently developed partial nitritation anammox (PNA) process, for example, consumes less energy for aeration and reduces nitrate in the effluent without requiring additional organic carbon. However, achieving stable nitritation (ammonium oxidation; $\mathrm{NH}_{4}^{+} \rightarrow \mathrm{NO}_{2}^{-}$) at mainstream conditions $\left(T=10-25^{\circ} \mathrm{C}, \mathrm{C}: \mathrm{N}>10\right.$, influent ammonium $<50 \mathrm{mgNH}_{4}-\mathrm{N} / \mathrm{L}$ and effluent $<1 \mathrm{mgNH}_{4}-\mathrm{N} / \mathrm{L}$ ) remains challenging. This study explores the potential and mechanism of nitrite-oxidizing bacteria (NOB) suppression in a bottom-fed sequencing batch reactor (SBR). Two bench-scale $(11 \mathrm{~L})$ reactors and a pilot-scale reactor $\left(8 \mathrm{~m}^{3}\right)$ were operated for over a year and were fed with organic substrate depleted municipal wastewater. Initially, nitratation (nitrite oxidation; $\mathrm{NO}_{2}^{-} \rightarrow \mathrm{NO}_{3}^{-}$) occurred occasionally until an anaerobic phase was integrated into the operating cycle. The introduction of the anaerobic phase effectively suppressed the regrowth of NOB while nitritation was stable over 300 days, down to $8^{\circ} \mathrm{C}$ and at ammonium influent concentrations $<25 \mathrm{mgNH}_{4}-\mathrm{N} / \mathrm{L}$. Batch experiments and process data revealed that parameters typically affecting NOB growth (e.g., dissolved oxygen, alkalinity, trace elements, lag-phase after anoxia, free nitrous acid (FNA), free ammonia (FA), pH, sulfide, or solids retention time (SRT)) could not fully explain the suppression of nitratation. Experiments in which fresh nitrifying microbial biomass was added to the nitritation system indicated that NOB inactivation explained NOB suppression better than NOB washout at high SRT. This study concludes that bottom-fed SBRs with anaerobic phases allow for stable nitritation over a broad range of operational parameters. Coupling this type of SBR to an anammox reactor can enable efficient mainstream anammox-based wastewater treatment.

\section{* Corresponding author.}

E-mail addresses: Damian.hausherr@eawag.ch (D. Hausherr), Robert.niederdorfer@eawag.ch (R. Niederdorfer), Helmut.buergmann@eawag.ch (H. Bürgmann), Moritz.lehmann@unibas.ch (M.F. Lehmann), Paul.magyar@unibas.ch (P. Magyar), Joachim.mohn@empa.ch (J. Mohn), Eberhard.morgenroth@ifu.baug.ethz.ch (E. Morgenroth), Adriano.joss@eawag.ch (A. Joss). 


\section{Introduction}

Nitrogen removal from wastewater is crucial to alleviate eutrophication in receiving bodies of water. Mainstream partial nitritation anammox (PNA) reduces aeration requirements for nitrogen removal and unlocks additional organic substrate for energy generation (Third et al., 2001). Thus, PNA significantly reduces the energy needed for wastewater treatment and achieves high nitrogen removal (McCarty, 2018). There are two key elements for stable operation of PNA systems. First, due to the slow growth rate of anammox bacteria sufficient biomass retention is required. This challenge can be solved through numerous technologies, such as granulated sludge, biofilm formation on carriers, biomass retention via membranes and others (reviewed in Kosgey et al., 2021). Second, ammonia-oxidizing bacteria (AOB) must be enriched and nitrite-oxidizing bacteria (NOB) must be suppressed. This is challenging as both groups of organisms have similar growth requirements, are physiologically linked through the intermediate nitrification product $\left(\mathrm{NO}_{2}^{-}\right)$, and thus tend to co-occur in most environments.

Inhibiting the growth of NOB has been approached through a plethora of methods (reviewed in Agrawal et al., 2018; Cao et al., 2017; Li et al., 2018). One example is the treatment of sludge with free ammonia (FA) or free nitrous acid (FNA) (Kent et al., 2019; Park and Bae, 2009; Vadivelu et al., 2006; Zheng et al., 2021). An NOB lag phase (a period of NOB inactivity after anoxia) has also been shown to suppress NOB growth. Here, two distinct mechanisms may be responsible for NOB lag/inactivity after anoxia. First, nitrite is consumed through anammox or denitrification during anoxic periods. Hence, when aeration restarts, ammonia is available for AOBs, while, initially, nitrite for NOBs is not. Second, during prolonged anoxia NOBs start to degrade their aerobic enzymatic machinery, and, they require some time to resume their aerobic activity upon return to aerobic conditions (Brotto et al., 2015; Gilbert et al., 2014; Xiao et al., 2021). NOB have also been suppressed successfully by dual (dissolved oxygen (DO) and nitrite) substrate limitation (Laureni et al., 2019). Additionally, in granular sludge systems, the selection of AOB over NOB has been achieved by keeping the DO to total ammonia nitrogen (TAN) ratio low (Bartrolí et al., 2010; Isanta et al., 2015; Jemaat et al., 2013).

Despite these developments, long-term NOB suppression is not a simple task. It has been shown that NOB can adapt to high concentrations of FA (An et al., 2021; Laloo et al., 2018; Wong-Chong and Loehr, 1978) and low levels of DO (Liu and Wang, 2013). Cold temperatures $\left(<15^{\circ} \mathrm{C}\right)$ and relatively low ammonium concentrations are particularly conducive to the growth of NOB in nitritation reactors (Hellinga et al., 1998; Poot et al., 2016). For example, ammonium concentrations as low as $5-30 \mathrm{mgNH}_{4^{-}}$ $\mathrm{N} / \mathrm{L}$ can be found in countries with combined sewers, in which sewage and rainwater are mixed. The results of Isanta et al.'s (2015) model have shown, that DO/TAN control strategies may not work if the TAN is below $10 \mathrm{mgNH}_{4}-\mathrm{N} / \mathrm{L}$ in the reactor.

Therefore, methods resulting in strong, reliable, and cost-effective NOB suppression under mainstream conditions have yet to be identified. An approach that has so far received little attention in this context is the use of plug flow reactors. A recent study has already demonstrated successful nitritation during operation with a continuous plug flow reactor fed with municipal wastewater ( $45 \mathrm{mgNH}_{4}-\mathrm{N} / \mathrm{L}$ and $150-180 \mathrm{mgCOD} / \mathrm{L}$ ) (Feng et al., 2021). In this study the use of multiple aerobic and anoxic compartments with wastewater residence times of $\mathrm{t}_{\text {anoxic }}: \mathrm{t}_{\text {aerobic }}>3$ was important to effectively suppress NOBs (decrease of relative abundance from $1 \%$ to $0.2 \%$ ). Yet, it is important to note that the study did not investigate nitritation at lower temperatures $\left(<15{ }^{\circ} \mathrm{C}\right)$. Instead of multiple flow- through compartments, a bottom-fed sequencing batch reactors (SBR) might bring additional benefits. The plug flow feed in SBRs can enhance the formation of granules, which have shown great potential for the suppression of NOB. However, to achieve sludge granulation most studies have used synthetic wastewater, or have added additional chemical oxygen demand (COD), especially in the form of acetate, to their influent (Kent et al., 2019; Reino et al., 2016; Wang et al., 2021), which does not represent realistic conditions. Additional potential advantages of a bottom-fed (SBR) lie in the relatively high ammonium concentrations at the beginning of the reaction phase, which allow for a high DO while still maintaining a low DO/TAN ratio. Furthermore, the anoxic/anaerobic feeding phase may increase NOB decay (Liu et al., 2021). An intermittent aeration regime can also be used to further repress NOB growth (Regmi et al., 2014; Sui et al., 2020).

It is, however, still unclear whether sludge granulation is achievable with carbon-depleted municipal wastewater and whether nitritation is stable in a bottom-fed SBR. To address these aspects, three SBRs $(11 \mathrm{~L}, 11 \mathrm{~L}$, and $8 \mathrm{~m}^{3}$ ) were operated for over a year with carbon-depleted municipal wastewater. To shed light on sludge granulation and nitritation efficiency, three key variables were investigated: sludge characteristics, nitrifier activity, and the microbial community.

After showing that stable nitritation is feasible, batch and continuous experiments were designed to explore the mechanisms responsible for NOB suppression. An understanding of the relative importance of different hypothesized NOB suppression mechanisms (e.g., substrate limitation, inhibition, toxicity and lag-phase) is valuable in reactor operation and design optimization.

\section{Materials and methods}

\subsection{Wastewater characteristics}

Municipal wastewater from the city of Dübendorf, Switzerland, was used in this study. The wastewater was screened before entering a primary sedimentation tank (hydraulic retention time (HRT) $0.5-1$ h). The wastewater composition after primary sedimentation is shown in Table 1 . The wastewater was further pretreated (carbon removed) in an $8 \mathrm{~m}^{3} \mathrm{SBR}$ (R-Carb), which is further described in the supplementary information (SI, Section 1.2). R-Carbs effluent composition is listed in Table 1. The effluent of R-Carb was used as the influent for the nitritation reactors.

\subsection{Reactors used in this study}

R1-PN is a bench-scale (11 L working volume) SBR with a height-todiameter ratio of 8.3 (SI, Fig. S1). Over the course of this study, it was operated in five different ways (Phase I-V), as shown in Table 2. Rain-events can strongly reduce influent ammonium concentrations (down to $5 \mathrm{mgNH}_{4}-\mathrm{N}$ / L). Therefore, since many nitritation system experience instabilities at such low ammonium concentrations, the influent was augmented with external ammonium $\left(\mathrm{NH}_{4} \mathrm{Cl}\right)$. In phases I-III, the reactor was operated with repeating aerobic (40 min) and anoxic ( $20 \mathrm{~min})$ steps. A setpoint of $1 \mathrm{mg} / \mathrm{L}$ DO was maintained during the aerobic phases. During phases IV and V, a constant aeration rate (instead of aerobic/anoxic cycles) of 75-350 $\mathrm{mL} / \mathrm{min}$ was applied during the aeration step ( $\mathrm{DO}=0.1-3 \mathrm{mg} / \mathrm{L}$ ). The aeration step was terminated either after a certain amount of time had passed (1500-21,600 s) or when the $\mathrm{pH}$ dropped below 7.2. The maximum aeration time was adjusted based on activity measurements to reach a residual ammonium concentration of $5-30 \mathrm{mgNH}_{4}-\mathrm{N} / \mathrm{L}$ (see Table 2). The resulting

Table 1

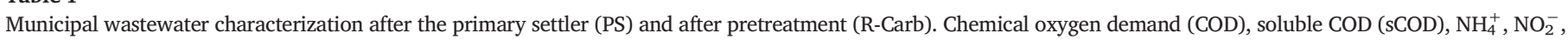
$\mathrm{NO}_{3}^{-}, \mathrm{PO}_{4}^{3-}$, total nitrogen (TN) and total phosphorus (TP) average values $(n=8)$ and standard deviations are given. TN and TP were only measured in the influent.

\begin{tabular}{|c|c|c|c|c|c|c|c|c|}
\hline Effluent & COD [mg/L] & sCOD [mg/L] & $\mathrm{TN}$ [mg/L] & $\mathrm{NH}_{4}-\mathrm{N}[\mathrm{mg} / \mathrm{L}]$ & $\mathrm{NO}_{2}-\mathrm{N}[\mathrm{mg} / \mathrm{L}]$ & $\mathrm{NO}_{3}-\mathrm{N}[\mathrm{mg} / \mathrm{L}]$ & $\mathrm{PO}_{4}-\mathrm{P}[\mathrm{mg} / \mathrm{L}]$ & $\mathrm{TP}$ [mg/L] \\
\hline PS & $469 \pm 235$ & $277 \pm 189$ & $47 \pm 12$ & $25 \pm 7$ & $0.3 \pm 0.03$ & $0.6 \pm 0.5$ & $1.7 \pm 1.2$ & $5.2 \pm 1.6$ \\
\hline R-Carb & $137 \pm 81$ & $51 \pm 22$ & - & $20 \pm 8$ & $0.3 \pm 0.1$ & $0.4 \pm 0.5$ & $1.2 \pm 0.5$ & - \\
\hline
\end{tabular}


Table 2

Reactor operation characteristics for different phases in R1-PN and R3-PN.

\begin{tabular}{|c|c|c|c|c|c|c|c|c|c|}
\hline Phase & $\begin{array}{l}\text { Days of } \\
\text { operation }\end{array}$ & $\begin{array}{l}\text { Sedimentation } \\
{[\mathrm{s}]}\end{array}$ & $\begin{array}{l}\text { Decantation } \\
{[\mathrm{s}]}\end{array}$ & $\begin{array}{l}\text { Bottom } \\
\text { feeding } \\
{[\mathrm{s}]}\end{array}$ & $\begin{array}{l}\text { Anaerobic } \\
\text { stirring }[\mathrm{s}]\end{array}$ & $\begin{array}{l}\text { Aeration and } \\
\text { stirring }[\mathrm{s}]\end{array}$ & $\begin{array}{l}\text { Ammonium } \\
\text { augmentation of } \\
\text { influent }\left[\mathrm{mgNH}_{4}-\mathrm{N} / \mathrm{L}\right]\end{array}$ & $\begin{array}{l}\text { Ammonium } \\
\text { residual in effluent } \\
{\left[\mathrm{mgNH}_{4}-\mathrm{N} / \mathrm{L}\right]}\end{array}$ & Questions \\
\hline \multicolumn{10}{|l|}{ R1-PN } \\
\hline I & $0-55$ & 300 & - & 1800 & - & $7200-14,400$ & 10 & $10 \pm 5$ & I-III: Is sludge granulation through short \\
\hline II & $56-106$ & 900 & - & 1800 & - & $7200-14,400$ & 40 & $30 \pm 5$ & sedimentation and upflow possible? Is \\
\hline III & $107-132$ & 300 & - & 1800 & - & $7200-14,400$ & 40 & $30 \pm 5$ & nitritation achieved and stable? \\
\hline IV & $133-267$ & 800 & - & 1800 & 3600 & $7200-21,600$ & 40 & $30 \pm 5$ & IV: Is nitritation stable with an anaerobic phase? \\
\hline $\mathrm{V}$ & $268-470$ & 800 & - & 1800 & 3600 & $1500-7200$ & 10 & $10 \pm 5$ & $\begin{array}{l}\text { V: Is nitritation stable at low } \mathrm{NH}_{4}^{+} \text {concentrations? } \\
\text { At high SRT? }\end{array}$ \\
\hline \multicolumn{10}{|l|}{ R3-PN } \\
\hline I & $0-180$ & 900 & 3600 & 7200 & 3600 & $1800-14,400$ & - & $35 \%$ & I: Is replication at pilot scale possible? \\
\hline II & $180-430$ & 900 & 3600 & 3600 & $5400^{\mathrm{a}}$ & $1800-10,800$ & - & $35 \%$ & II: Can nitritation rates be increased? \\
\hline
\end{tabular}

a R3-PN still received influent during the first $3600 \mathrm{~s}$ of anaerobic stirring.

HRTs ranged from 2.4-6.5 h. On day 346, a sieve with a pore size of $50 \mu \mathrm{m}$ was installed to retain suspended solids in the effluent (see Fig. 1). Until day 470 , the sieve's content was centrifuged daily; the resulting pellet was, after resuspension, reintroduced to the reactor. R1-PN features a pH electrode (CPS11, Endress + Hauser, Switzerland) and a DO electrode (COS61, Endress + Hauser, Switzerland). The inoculum for R1-PN was taken from a conventional nitrification/denitrification reactor R-ND (described in SI, Section 1.2).

R2-PN is a bench-scale ( $11 \mathrm{~L}$ working volume) SBR with a height-todiameter ratio of 2 (SI, Fig. S2). It was first (days 1-30) operated in the same manner as R1-PN in phase IV; for days 31-400 it was operated like R1-PN in phase V but without sludge recirculation. The SRT was not controlled and HRT ranged from 4.2-6.5 h. The reactor was also inoculated with sludge from R-ND (SI, Section 1.2). During certain periods (see SI, Fig. S7), $\mathrm{KNO}_{3}\left(20-30 \mathrm{mgNO}_{3}-\mathrm{N} / \mathrm{L}\right), \mathrm{KH}_{2} \mathrm{PO}_{4} / \mathrm{K}_{2} \mathrm{HPO}_{4}(10-15 \mathrm{mgPO}-\mathrm{P} / \mathrm{L}$ ), and $\mathrm{CaCO}_{3}\left(50 \mathrm{mgCO}_{3} / \mathrm{L}\right)$ were added to the influent (the rationale for these additions is provided in SI: 3.4.1, 3.1.4 and 3.1.3, respectively).

R3-PN is a pilot-scale $\left(8 \mathrm{~m}^{3}\right.$ working volume) SBR with a height-todiameter ratio of 0.9 (SI, Fig. S3). R3-PN received the same influent as R1-PN and R2-PN (i.e., the effluent of R-Carb) and was inoculated with the same sludge (i.e., sludge from R-ND). The operation of the pilot-scale was similar to that of the bench-scale reactors with two exceptions (Table 2). First, after sedimentation, $45 \%$ of the reactor volume was decanted, after which $80 \%$ of the remaining volume was displaced via plug flow feeding from the bottom of the reactor. Thereafter, the effluent valve was closed and the missing $45 \%$ of the reactor volume was re-filled ( $89 \%$ volume exchange in total). During this re-filling step the reactor was either unstirred (Phase I) or stirred (Phase II). Second, the target ammonium concentration at which aeration should stop was determined via an algorithm. For each SBR cycle, the algorithm received the ammonium concentration at the end of the anaerobic stirring phase, then calculated and set the targeted ammonium concentration as $35 \%$ of this initial ammonium concentration. The HRT varied between 5.9 and $9.3 \mathrm{~h}$. The SRT was only dependent on the sludge lost in the effluent (SRT $=7-40 \mathrm{~d}$ ). Additional information regarding the operation of R3-PN is found in the SI (Section 1.2).

An overview of the timeline of the reactors and different experiments is given in the supplementary information (SI, Fig. S4).

\subsection{Analytics}

Samples were centrifuged $(3200 \mathrm{~g}, 2 \mathrm{~min})$ and filtered $(0.45 \mu \mathrm{m}$, Macherey-Nagel) prior to ammonium, nitrite, nitrate, and phosphate measurement with ion chromatography (Metrohm AG, 761 Compact IC and 881 Compact IC pro, Switzerland) and soluble COD measurements (Hach Lange, LCK 314, Germany). COD, total nitrogen, and total phosphorus were quantified photometrically with test kits (Hach Lange, LCK 114, 338, and 348, respectively, Germany). Total suspended solids (TSS),

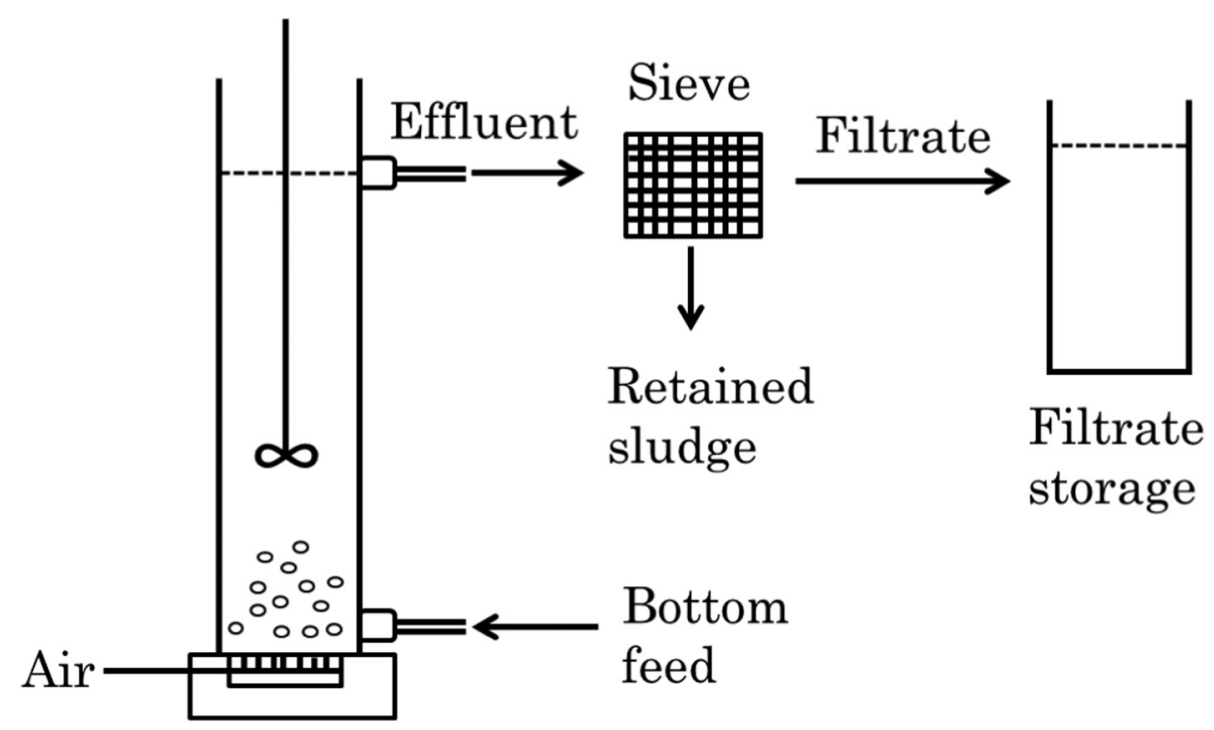

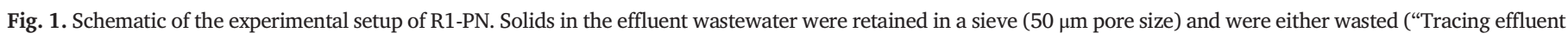

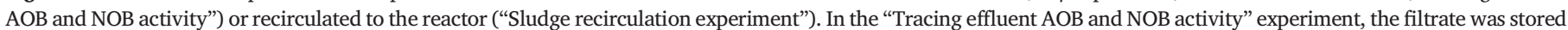
in an additional barrel (filtrate storage). 
volatile suspended solids (VSS), and the sludge volume index (SVI) were measured according to (APHA et al., 2012) standard protocols.

The floc size distribution was determined by static light scattering using a Beckman Coulter (Pasadena, CA, USA) LS 13320 particle size analyzer with a Universal Liquid Module for the volume percentile distributions.

\subsection{Calculations}

The nitritation ratio (NR) is a function of nitrite and nitrate effluent concentrations ( $\mathrm{C}_{\mathrm{NO} 2}$ and $\mathrm{C}_{\mathrm{NO} 3}$, respectively). Full nitrification occurs when $\mathrm{NR}=-1$; full nitritation is achieved when $\mathrm{NR}=1$, provided that there is no nitrite nor nitrate at the start of the aeration step.

$N R=\frac{C_{N O 2}-C_{N O 3}}{C_{N O 2}+C_{N O 3}}$

with $\mathrm{C}_{\mathrm{NO} 2}$ in $\left[\mathrm{mgNO}_{2}-\mathrm{N} / \mathrm{L}\right]$ and $\mathrm{C}_{\mathrm{NO} 3}$ in $\left[\mathrm{mgNO}_{3}-\mathrm{N} / \mathrm{L}\right]$.

Nitrifier activity was individually measured for $\mathrm{AOB}$ and $\mathrm{NOB}\left(\mathrm{r}_{\mathrm{AOB}}\right.$ and $\mathrm{r}_{\mathrm{NOB}}$ ) during the aerated phases. In short, 5-15 min after aeration began, 2-6 samples were collected between 5 and 60 min depending on nitrifier activity. The rate of change in substrate $\left(\mathrm{NH}_{4}-\mathrm{N}\right)$ concentration and product $\left(\mathrm{NO}_{3}-\mathrm{N}\right)$ accumulation over time were then calculated.

$r_{A O B}=\frac{d N H_{4}^{+}}{d t}$

$r_{N O B}=\frac{d N O_{3}^{-}}{d t}$

with $\mathrm{r}_{\mathrm{AOB}}$ in $\left[\mathrm{mgNH}_{4}-\mathrm{N} / \mathrm{L} / \mathrm{h}\right]$ and $\mathrm{r}_{\mathrm{NOB}}$ in $\left[\mathrm{mgNO}_{3}-\mathrm{N} / \mathrm{L} / \mathrm{h}\right]$.

To monitor the net change of AOB and NOB activity $\left[r_{\mathrm{AOB}, \Delta}(\mathrm{n})\right.$ and $\mathrm{r}_{\mathrm{NOB}, \Delta}(\mathrm{n})$ ] between $\mathrm{t}_{0}$ to $\mathrm{t}_{\mathrm{n}}$ in R1-PN, during the "Sludge recirculation experiment" (2.6.2), the following equations were set up:

$r_{A O B},\left(t_{n}\right)=r_{A O B}\left(t_{n}\right)+\sum_{i=0}^{i=n} \frac{Q\left(t_{i}\right) *\left(t_{i+1}-t_{i}\right)}{V_{R}} * r_{A O B, E f f}\left(t_{i}\right)-r_{A O B}\left(t_{0}\right)$

$r_{N O B},\left(t_{n}\right)=r_{N O B}\left(t_{n}\right)+\sum_{i=0}^{i=n} \frac{Q\left(t_{i}\right) *\left(t_{i+1}-t_{i}\right)}{V_{R}} * r_{N O B, E f f}\left(t_{i}\right)-r_{N O B}\left(t_{0}\right)$

where $\mathrm{r}_{\mathrm{AOB}, \Delta}\left(\mathrm{t}_{\mathrm{n}}\right)\left[\mathrm{mgNH}_{4}-\mathrm{N} / \mathrm{L} / \mathrm{h}\right]$ is the difference between AOB in the reactor at $t_{0}$ and $t_{n}$ as well as the sum of activity lost during $t_{n}-t_{0}$ in the effluent. $\mathrm{Q}$ is the influent flow rate $[\mathrm{L} / \mathrm{h}]$ at time $\mathrm{t}_{\mathrm{i}}$, the time difference between sampling events $t_{i+1}$ and $t_{i}[h], V_{R}$ is the working volume of the reactor [L] and $r_{A O B, E f f}$ is the AOB activity in the effluent at time point $t_{i}$. The same applies for NOB in Eq. (5) but in $\left[\mathrm{mgNO}_{3}-\mathrm{N} / \mathrm{L} / \mathrm{h}\right]$. An illustration of Eqs. (4) and (5) is provided in the supplementary information (SI, Fig. S5).

The SRT [d] is calculated as follows:

$S R T=\frac{V_{R} * T S S_{R}}{Q * T S S_{E f f}}$

where $V_{R}$ is the working volume of the reactor $(11 \mathrm{~L}$ or $8000 \mathrm{~L}), \mathrm{TSS}_{\mathrm{R}}$ is the measured TSS $[\mathrm{g} / \mathrm{L}]$ in the reactor, $\mathrm{Q}$ is the effluent volume per day $[\mathrm{L} / \mathrm{d}]$ and $\mathrm{TSS}_{\mathrm{Eff}}$ is the measured TSS $[\mathrm{g} / \mathrm{L}]$ in the effluent of the reactor. When the effluent sludge was retained by the sieve, the SRT was calculated using the measured TSS in the filtrate (Fig. 1). Sampling losses were neglected (e.g., $10 \mathrm{~mL}$ mixed liquor per week for floc size distribution measurement). No sludge was purposely wasted, throughout the entire study.

The aerobic SRT ( $\mathrm{SRT}_{\mathrm{aer}}$ ) was calculated by multiplying the SRT by the aerobic fraction $\left(\mathrm{f}_{\text {Aer }}\right)$ of the total SBR cycle time.

$f_{\text {Aer }}=\frac{t_{\text {aer }}}{t_{\text {Cycle }}}$

where $t_{\mathrm{aer}}$ is the duration of aeration [s] and $\mathrm{t}_{\text {Cycle }}$ is the duration of a complete SBR cycle [s].
The expected nitrate concentration over time $\left(\mathrm{NO}_{3}(\mathrm{t}),\left[\mathrm{mgNO}_{3}-\mathrm{N} /\right.\right.$ $\mathrm{L}])$ due to NOB growth in a batch reactor was calculated according to Eq. (8).

$N O_{3}(t)=\frac{1}{Y_{N O B}} * X_{N O B, 0} * e^{\mu * t}+N O_{3,0}$

with $\mathrm{Y}_{\mathrm{NOB}}=0.07 \mathrm{mgVSS} / \mathrm{mgN}$ (Blackburne et al., 2007) and $\mathrm{NO}_{3,0}$ (initial nitrate concentration) $=0.3 \mathrm{mgNO}_{3}-\mathrm{N} / \mathrm{L}$. $\mathrm{X}_{\mathrm{NOB}, 0}$ (initial concentration of NOB $[\mathrm{mgVSS} / \mathrm{L}]$ ) and $\mu$ (growth rate of NOB $\left[\mathrm{d}^{-1}\right]$ ) were obtained by fitting Eq. (8) to experimental data (Results 3.2).

Under non-limiting conditions, the minimal necessary aerobic $\mathrm{SRT}_{\mathrm{aer}}$, $\min$ was calculated according to Eq. (9).

$S R T_{a e r, \min }=\frac{1}{\mu_{\max }-b}$

with $\mathrm{SRT}_{\text {aer,min }}[\mathrm{d}], \mu_{\max }$ as the specific maximum growth rate $\left[\mathrm{d}^{-1}\right]$ and $\mathrm{b}$ as the specific decay coefficient $\left[\mathrm{d}^{-1}\right]$.

\subsection{Batch experiment: NOB activity and growth}

To investigate the maximum growth rate of NOB the following experiment was set up: Sludge from R1-PN was re-suspended in $5400 \mathrm{~mL}$ of fresh R-Carb effluent (Table 1) and equally distributed ( $900 \mathrm{~mL}$ ) between six 1 L beakers (B1, B2, B3, B4, B5, B6) at 1.4 gTSS/L. All beakers were stirred at $50 \mathrm{rpm}$ and aerated. DO was measured periodically with a hand-held DO probe; it was always $>6 \mathrm{mgO}_{2} / \mathrm{L}$. The ammonium contained in the wastewater was augmented with $80 \mathrm{mg}$ of $\mathrm{NH}_{4} \mathrm{Cl}$ in each beaker, resulting in an $\mathrm{NH}_{4}-\mathrm{N}$ concentration of $48 \mathrm{mgNH}_{4}-\mathrm{N} / \mathrm{L}$. Beakers 3 and 4 , and 5 and 6 were additionally amended with $1 \mathrm{~mL}$ and $3 \mathrm{~mL}$ of a trace elements solution (adapted from Layer et al., 2019; see SI, Table S1). Samples were drawn 1-2 times daily for 6.5 days.

\subsection{Addition of nitrifying sludge to R1-PN}

Understanding the fate of the NOB in R1-PN was difficult, because almost no NOB activity was ever present after the introduction of the anaerobic phase (Results 3.1.2). Thus, to explore nitrifier activity, in greater detail, two experiments were conducted in which fresh nitrifying biomass (which contained active NOB) was added to R1-PN.

In short, $18 \mathrm{~L}$ and $12 \mathrm{~L}$ of mixed liquor from R-ND were centrifuged for $5 \mathrm{~min}$ at $4000 \mathrm{~g}$, the resulting pellets were re-suspended and poured into R1PN. A total of 33 gTSS and 19 gTSS from R-ND, were added for the "Tracing effluent AOB and NOB activity" and the "Sludge recirculation experiment", respectively. R1-PN was operated as described in Table 2 (phase V). A sieve with a pore size of $50 \mu \mathrm{m}$ was also installed to retain suspended solids in the effluent (Fig. 1).

\subsubsection{Tracing effluent $A O B$ and $N O B$ activity}

The filtrate was pumped into a $200 \mathrm{~L}$ barrel that had been added to the setup (Fig. 1, filtrate storage). AOB and NOB activity, as well as TSS, were monitored in the reactor, the effluent sludge, and the filtrate every 1-2 days. The retained effluent sludge was wasted after AOB and NOB activity had been determined. During the aerated phase, the average DO was $3 \pm 0.3 \mathrm{mg} / \mathrm{L}$. The temperature was not controlled (17.3 \pm $\left.0.4{ }^{\circ} \mathrm{C}\right)$.

\subsubsection{Sludge recirculation experiment}

In contrast to the "Tracing effluent $\mathrm{AOB}$ and NOB activity" experiment, the effluent sludge retained by the sieve was not discarded but instead was returned to the reactor each day. TSS, AOB, and NOB activity in the reactor were measured daily. During the aerated phase, average the DO was $3.9 \pm 0.5 \mathrm{mg} / \mathrm{L}$. The temperature was not controlled (16 \pm $\left.0.8{ }^{\circ} \mathrm{C}\right)$. 


\subsection{Microbial community analysis}

Microbial community composition was determined via DNA extraction and $16 \mathrm{~S}$ rRNA gene amplicon sequencing (V3-V4, primer pair 341F and 805R). The analysis was performed by DNASense (Aalborg, Denmark). An extensive description of the method can be found in the supplementary information (SI, 1.6).

In short, DNA extraction was performed using the standard protocol for the FastDNA Spin Kit for soil (MP Biomedicals, USA) with the following exceptions: $500 \mu \mathrm{L}$ of sample, $480 \mu \mathrm{L}$ sodium phosphate buffer, and $120 \mu \mathrm{L}$ MT buffer were added to a Lysing Matrix E tube. Bead beating was performed at $6 \mathrm{~m} / \mathrm{s}$ for $4 \times 40 \mathrm{~s}$ (Albertsen et al., 2015). DNA concentration was measured using a Qubit dsDNA HS/BR Assay kit (Thermo Fisher Scientific, USA).

Bacteria 16S rRNA gene region V3-4 sequencing libraries were prepared by a custom protocol based on an existing Illumina protocol (Illumina, 2015). The resulting amplicon libraries were purified using the standard protocol for Agencourt Ampure XP Beads (Beckman Coulter, USA). Sequencing libraries were prepared from the purified amplicon libraries using a second PCR. DNA concentration was measured using a Qubit dsDNA HS Assay kit (Thermo Fisher Scientific, USA). Gel electrophoresis using a Tapestation 2200 and D1000/high sensitivity D1000 ScreenTapes (Agilent, USA) were used to validate product size and the purity of a subset of sequencing libraries. The samples were paired-end sequenced $(2 \times 300 \mathrm{bp})$ on a MiSeq (Illumina, USA) using a MiSeq Reagent kit v3 (Illumina, USA). Two samples (Day 334 and 360) were sequenced by Novogen, V3-4 region, and Illumina sequencing. Forward and reverse reads feature classification was performed with the Kraken2 package (Version 2.1.1) with the paired reads setting enabled. Taxonomy assignment was based on the Silva_138_2kdb database.

\section{Results}

\subsection{Nitritation robustness and reproducibility}

\subsubsection{R1-PN start-up}

Bottom-feeding and short settling times were initially selected to increase biomass granulation during phases I-III (Days 0-132, Table 2). The fraction of flocs larger than $250 \mu \mathrm{m}$ increased from 10 to $15 \%$ to $35-45 \%$ (SI, Fig. S6, day 0-100), but the SVI measurements indicated floccular rather than granular characteristics, i.e., $\mathrm{SVI}_{30}>100 \mathrm{~mL} \cdot \mathrm{gTSS}^{-1}$ and $\mathrm{SVI}_{30}: \mathrm{SVI}_{5}=0.5-0.7$ (SI, Fig. S18). The nitritation ratio (NR) was not stable during this period; the effluent occasionally contained more nitrate than nitrite, i.e., $\mathrm{NR}<0$ (Fig. 2A, days $0-132$ ).
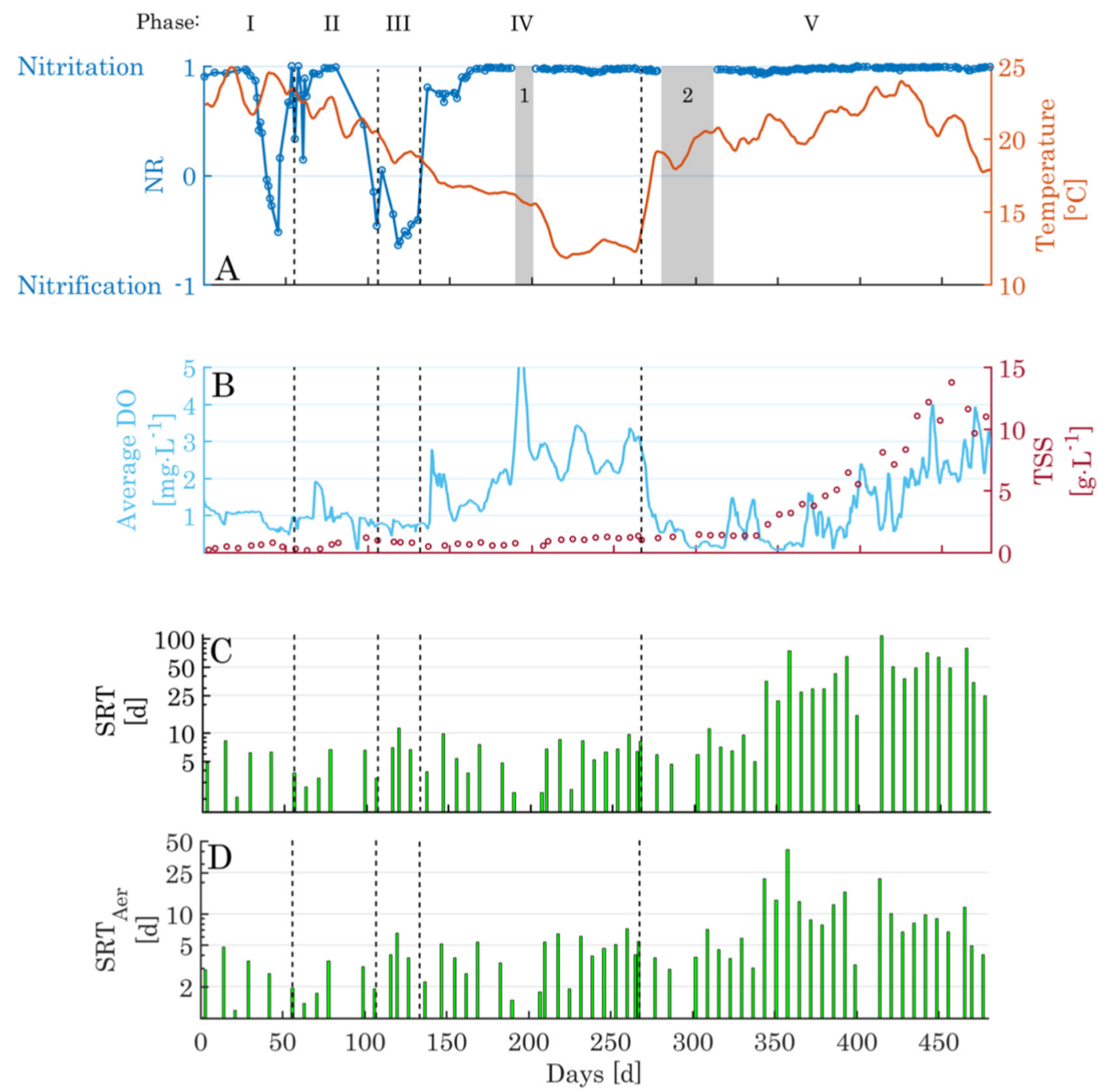

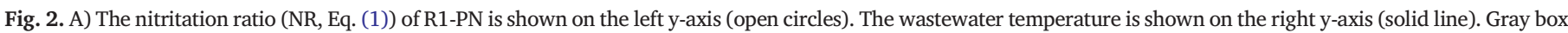

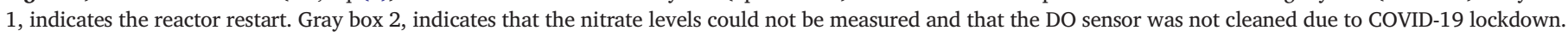

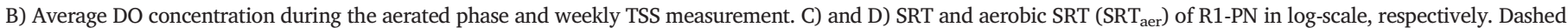
lines indicate the start and end points of the five different phases, respectively. 


\subsubsection{Lasting nitritation after introduction of anaerobic phase}

On day 132, with the initial intent to support granulation, an anaerobic phase was added to the SBR cycle before the aerobic phase (Table 2, phase IV). Additionally, during the aerobic phase, aeration was changed from aerobic/anoxic cycles (40 min with a DO setpoint of $1 \mathrm{mg} / \mathrm{L}$, followed by $20 \mathrm{~min}$ anoxic) to a constant aeration rate of $75 \mathrm{~mL} / \mathrm{min}$ resulting in a DO of 1-3 mg/L (Fig. 2B). These changes did not increase sludge granulation (SI, Figs. S6 and S18). However, within four days the reactor switched from nitrate accumulation to nitrite accumulation (Fig. 2A, day 132-136, third dashed vertical line).

\subsubsection{Nitritation ratio in $R 1-P N$}

After the introduction of the anaerobic phase, nitritation was stable for two months (Fig. 2A, days 136-191). On day 191, a malfunction led to the loss of $90 \%$ of the sludge from R1-PN. Fresh nitrifying sludge from R-ND was added to the reactor along with the remaining $10 \%$ of the nitritation sludge (day 192). Six days later (day 198), when monitoring was restarted (after Christmas break), nitrite oxidation had already largely vanished.

On day 206, the reactor temperature was reduced to $11 \pm 1{ }^{\circ} \mathrm{C}$ for two months (until day 267) without any appreciable decrease in the nitritation ratio. Starting on day 268 , the ammonium influent concentration was decreased from $60 \pm 10$ to $25 \pm 10 \mathrm{mgNH}_{4}-\mathrm{N} / \mathrm{L}$ and the residual ammonium concentration (i.e., ammonium effluent concentration) was reduced from $30 \pm 5$ to $10 \pm 5 \mathrm{mgNH}_{4}-\mathrm{N} / \mathrm{L}$.

On day 346 , a sieve was installed (mesh size $50 \mu \mathrm{m}$ ) to retain the solids in the effluent (Fig. 1). These solids were returned to the reactor each day,

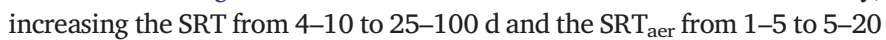
d calculated by Eqs. (6) and (7) (Fig. 2C and D). Due to the SRT increase, TSS increased from 0.5 up to 14 gTSS/L (Fig. 2B). Lastly, from day 370 to day 400 , the aeration rate was gradually increased from $75 \mathrm{~mL} / \mathrm{min}$ to $350 \mathrm{~mL} / \mathrm{min}$ and then kept at $350 \mathrm{~mL} / \mathrm{min}$. This resulted in a DO concentration of 1.5-3 mg/L, even at a high TSS concentration (Fig. 2B). Throughout all these changes, the nitritation ratio was stable and close to 1 .

\subsubsection{Microbial community dynamics in R1-PN}

During the first 132 days, nitritation in R1-PN was unstable and nitrate repeatedly dominated the effluent. The microbial community composition, according to a $16 \mathrm{~S}$ rRNA gene amplicon sequencing analysis, confirmed this observation. More precisely, NOB abundance (only Nitrotoga detected) was low $(0.1 \%)$ on day 20 (Fig. 3B), while nitrite dominated the effluent (Fig. 2A). Whereas, on days 41 and 115, when nitratation increased (NR $<0$ ), relative NOB abundances of $0.8 \%$ and $2.3 \%$, respectively, were determined. A relative NOB abundance of $0.9 \%$ was determined on day 158 , when the NR was 0.85 . From day 170 onwards, nitrite dominated the effluent $(\mathrm{NR} \approx 1)$ and the relative NOB abundance was again very low at only $0-0.05 \%$ of the bacterial community. The relative abundance of AOB (Nitrosomonadaceae) declined from $4.3 \%$ to $0.3 \%$ (Nitrosococcaceae abundance $=0-0.01 \%$ not shown) between days 0 and 360 . In the final microbial community sampling at day 481 , a significant change in the bacterial community composition was observed. The relative abundance of Chloroflexi, Firmicutes and Actinobacteria increased while Bacteroidetes decreased and almost no AOB (0.1\%) were detected (Fig. 3A and C). These changes in relative abundance, between day 360 and 481, occurred while the TSS increased from 2 to over 10 gTSS/L (Fig. 2B) and the NR remained high (Fig. 2A).

\subsubsection{Transition from nitrification to nitritation (R2-PN) and up-scaling (R3-PN)}

A new reactor, R2-PN, with different geometry than R1-PN (SI, Fig. S2), was inoculated with nitrifying sludge from R-ND and operated with the same SBR cycle as R1-PN (Table 2, Phase IV), i.e., sedimentation, bottomfeed, anaerobic phase followed by constant aeration. Within two weeks,
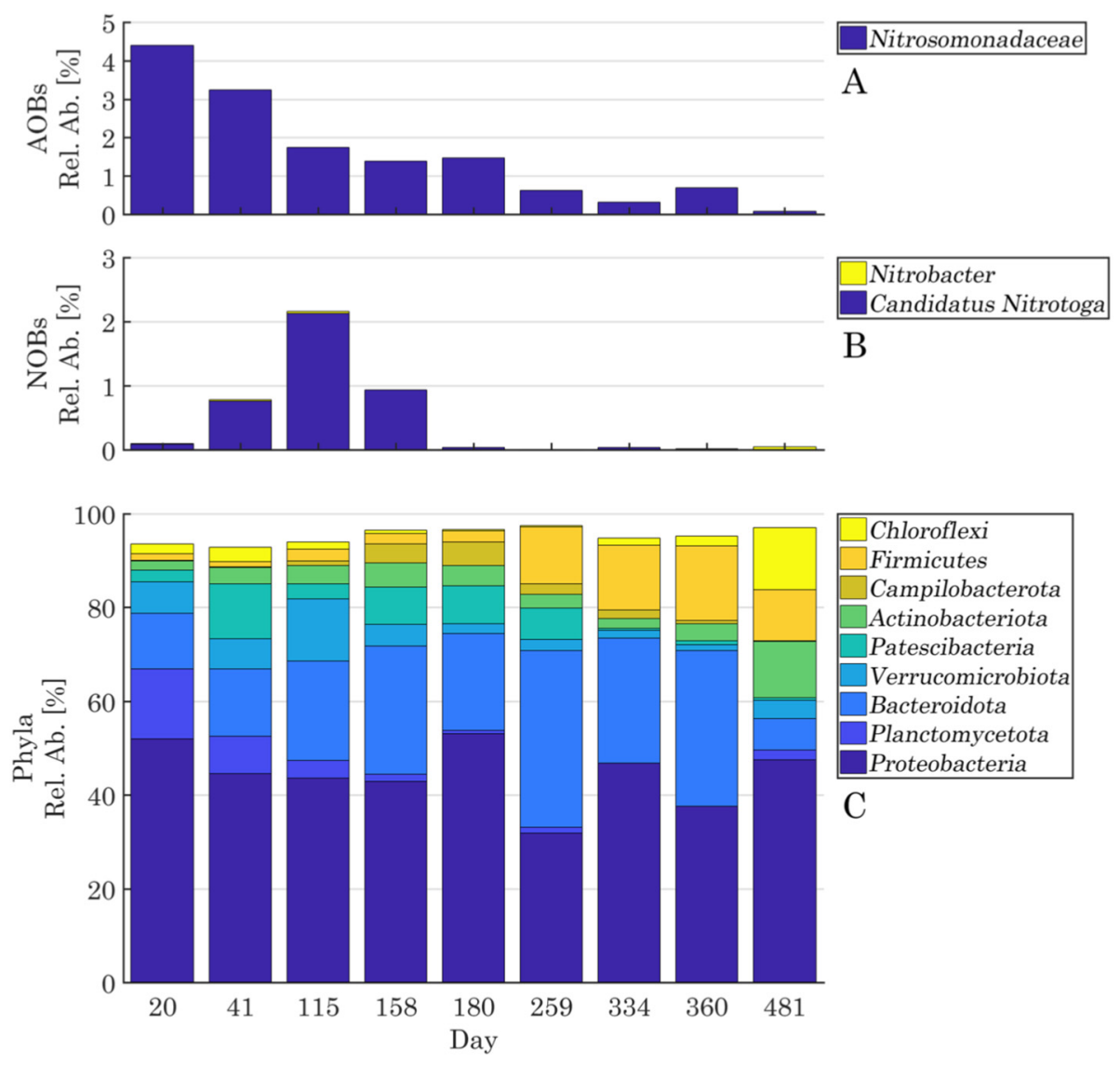

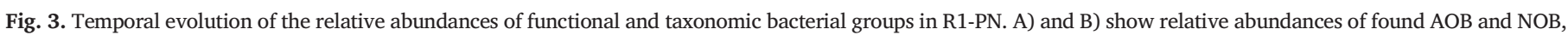
respectively. In panel C), the most abundant phyla are shown. 

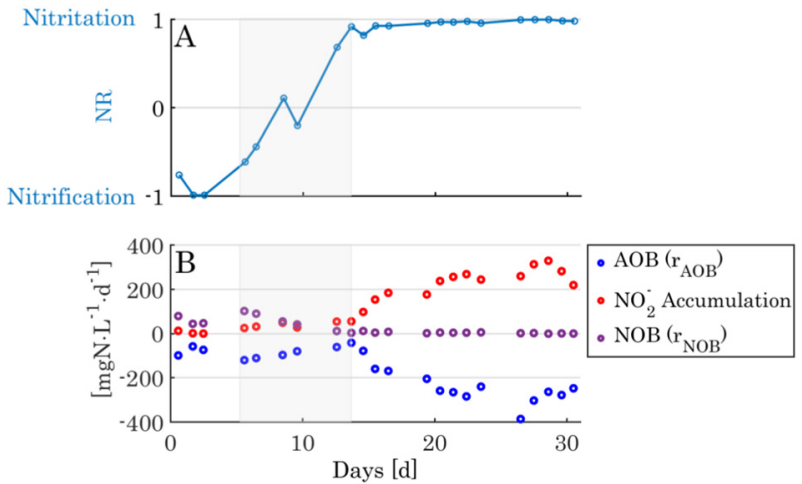

Fig. 4. A) The nitritation ratio (NR) of R2-PN. B) Nitrifier activity measured according to Eqs. (2) and (3) and the nitrite accumulation rate during aeration. Gray Box: Both AOB and NOB activity decreased while NR increased.

the system switched from complete nitrification to nitritation (Fig. 4A). Intriguingly, during the increase in NR (Fig. 4A, gray box), both $\mathrm{r}_{\mathrm{AOB}}$ and $\mathrm{r}_{\mathrm{NOB}}$ declined, but $\mathrm{r}_{\mathrm{NOB}}$ did so more significantly. Only after full nitritation was observed (i.e., $\mathrm{NR} \approx 1$ ) did $\mathrm{r}_{\mathrm{AOB}}$ increase. Nitritation was maintained in this reactor over the following year (SI, Fig. S7).

In R3-PN ( $8 \mathrm{~m}^{3}$ reactor volume), a significant lag phase was observed, during which full nitrification was measured (Fig. 5, days 0-80). But then, within 30 days, the system shifted from nitrification to nitritation. Similar to R2-PN, shortly before the switch to nitritation a decrease in the ammonium oxidation rate was observed (while TSS even increased) (SI, Fig. S8). Without any significant contribution of NOB activity, nitritation was maintained down to wastewater temperatures of $8{ }^{\circ} \mathrm{C}$ and with a very low influent ammonium concentration of $20 \pm 8 \mathrm{mgNH}_{4}$ - $\mathrm{N} / \mathrm{L}$.

\subsection{NOB growth}

To quantify the maximum growth rate of the very small NOB population in the sludge of R1-PN, batch experiments were conducted (as described in Section 2.5). Fig. 6 shows the nitrate concentration increasing exponentially in aerated beakers inoculated with sludge from R1-PN, irrespective of trace element addition. Eq. (8) was fitted to the average nitrate concentration of all beakers. From the fit, $\mu_{\mathrm{NOB}}=0.58 \mathrm{~d}^{-1}$ (95\% confidence interval $[0.520 .63]$ ) and $\mathrm{X}_{0}=0.11 \mathrm{mgVSS} / \mathrm{L}$ ( $95 \% \mathrm{CI}$ [0.08 0.14]) were obtained. Under non-limiting growth conditions, Eq. (9) was used to determine the $\mathrm{SRT}_{\text {aer,min }}$. An SRT $\mathrm{aer}_{\text {min }}$ of $2.02 \mathrm{~d}\left(\right.$ at $20{ }^{\circ} \mathrm{C}$ ) was calculated with $\mathrm{b}=0.085 \mathrm{~d}^{-1}$ (Wiesmann, 1994).

\subsubsection{NOB washout and inactivation}

To shed light on the fate of the NOB two experiments were conducted as described in Section 2.6. In both experiments, nitrifying biomass from R-ND (which contained active NOB) was added to the nitritation biomass already present in R1-PN. The aim of the first experiment was to test if NOB were not retained in the sieve like the other flocs. AOB and NOB activity (normalized to TSS) was found to be similar in the reactor and the retained sludge

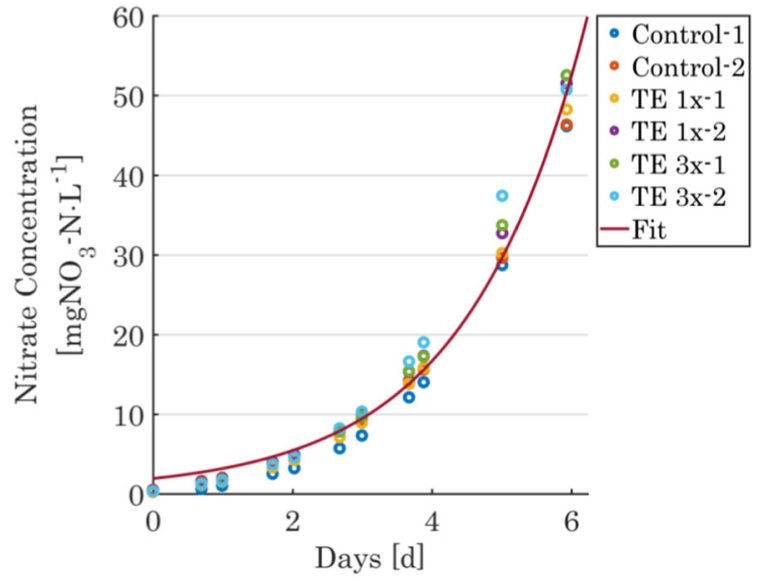

Fig. 6. Nitrate concentration over time in six aerated beakers inoculated with nitritation sludge from R1-PN and $0 \mathrm{~mL}$ (Control), $1 \mathrm{~mL}$ (TE $1 \times$ ) and $3 \mathrm{~mL}$ (TE $3 \times$ ) of a trace elements solution (SI, Table S1). Eq. (8) was fitted to the averaged data points of each sampling time.

but lower in the filtrate (Fig. 7A and B). Thus, AOB and NOB were retained in the sieve at an increased rate compared to overall TSS. The average TSS in the filtrate was $13.5 \pm 3.8 \mathrm{mgTSS} / \mathrm{L}$. Over eight days, the AOB activity per gram of TSS had increased by $38 \%$ in the reactor, whereas the NOB activity had declined by $77 \%$ (Fig. 7).

In the second experiment, the sludge retained by the sieve was not discarded but instead was recirculated to the reactor once per day. The TSS increased from $3.5 \mathrm{~g} / \mathrm{L}$ to $8 \mathrm{~g} / \mathrm{L}$ (130\% increase) over 22 days (SI, Fig. S9). The volumetric AOB activity increased by $207 \%$ (Fig. $8 \mathrm{~A}$ ), whereas the volumetric NOB activity decreased by $74 \%$ (Fig. 8B). The change in $\mathrm{AOB}$ and NOB activity was calculated according to Eqs. (4) and (5). In Fig. 8 all activity lost in the effluent up to each day is shown in yellow (SI, Eq. (S6)). On day 22 , only $26 \%$ of the initial NOB activity was measured (Fig. 8B, blue). From the "missing" $74 \%$ of NOB activity, just $15 \%$ can be explained by washout (Fig. 8B, yellow); $59 \%$ of the initial NOB activity cannot be accounted for (Fig. 8B, black bar). This negative change in the net NOB activity indicates NOB inactivation (SI, Fig. S5B).

A comprehensive range of parameters grouped into four categories (substrate limitation, toxicity and inhibition, lag-phase, and miscellaneous) were investigated to test their explanatory power regarding the significant reduction in NOB growth or high NOB decay (Table 3). These parameters were studied through experimental work and comparison with literature. Two examples are briefly presented here; a more detailed discussion of all parameters is provided in the supplementary information. (1) An increase in NOB decay could be linked to FNA concentrations. During regular reactor operation, no more than $25 \mathrm{mgNO}_{2}-\mathrm{N} / \mathrm{L}$ accumulated and the $\mathrm{pH}$ did not drop below 7.2. These conditions resulted in a maximal FNA concentration of 0.012 mgFNA/L (SI, Eq. (S2)). This maximal FNA concentration is still significantly below reported inhibitory concentrations of 0.03-2.8 mgFNA/L (Anthonisen et al., 1976; Zhang et al., 2010). Therefore, FNA is

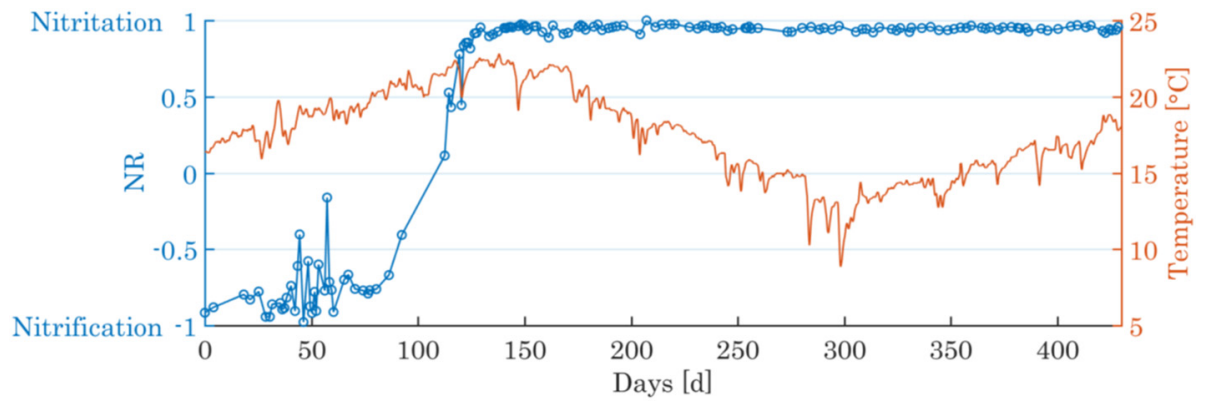

Fig. 5. Nitritation ratio and temperature in R3-PN ( $8 \mathrm{~m}^{3}$ reactor volume). 


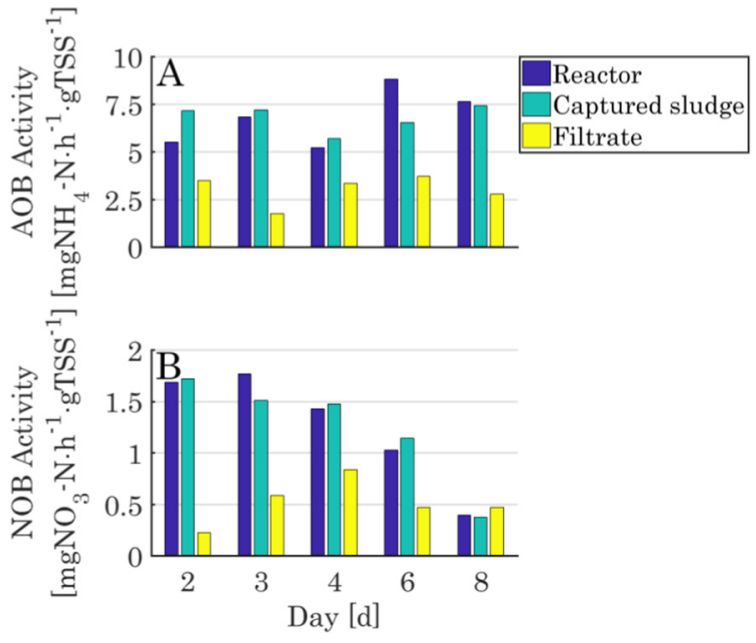

Fig. 7. AOB (A) and NOB (B) activity normalized to TSS were measured on five days, during the "Tracing effluent AOB and NOB activity" experiment, in R1-PN in the sludge retained by the sieve and in the filtrate.
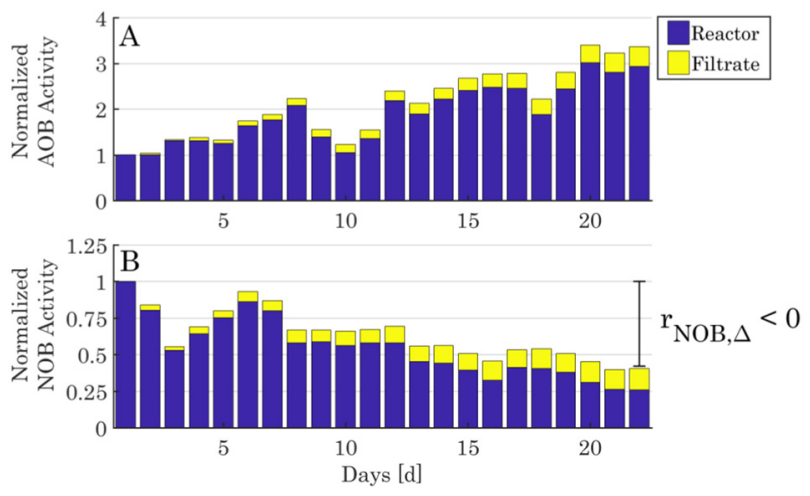

Fig. 8. A) AOB and B) NOB activity, normalized to the first day, measured in R1-PN over three weeks, with daily sludge recirculation. The estimated sum of AOB or NOB activity lost in the filtrate is shown in yellow. The black bar on day 22 indicates the negative change of NOB activity (Eq. (4)). (For interpretation of the references to color in this figure legend, the reader is referred to the web version of this article.)

not expected to strongly contribute to NOB suppression. (2) NOB being outcompeted has often been attributed to DO limitation, especially at low DO concentrations ( $<1 \mathrm{mgO}_{2} / \mathrm{L}$ ). The nitritation sludge is floccular (SI, Fig. S19) and mainly consists of small particles (SI, Fig. S6), thus no oxygen limitation due to strong mass transfer limitation is expected. Wijffels et al. (1991) reported an apparent $\mathrm{k}_{\mathrm{O} 2 \text {, NOB }}$ value of 0.54 $\mathrm{mgO}_{2} / \mathrm{L}$; a value of $0.13 \mathrm{mgO}_{2} / \mathrm{L}$ was determined in an $\mathrm{MBR}$ with small flocs (Manser et al., 2005). As demonstrated in Fig. 2 (Day $400-481$ ), an average DO concentration of $1.5-3 \mathrm{mgO}_{2} / \mathrm{L}$ was maintained for months, even with a high SRT. Furthermore, in the "Sludge recirculation experiment", the average DO was $3.9 \pm 0.5 \mathrm{mg} / \mathrm{L}$ and still NOB activity decreased. Hence, oxygen limitation is unlikely to be responsible for the absence of NOB.
After testing all parameters listed in Table 3, none of them seemed to be individually sufficient to explain the lack of NOB activity. Further information regarding these parameters and the experiments conducted is found in the supplementary information.

\section{Discussion}

4.1. Nitritation was achieved under various conditions (DO, SRT, temperature) and reached high ammonium oxidation rates

Stable nitrite accumulation was measured (Figs. 2A, 5, and SI, Fig. S7) over a year, even though municipal wastewater composition, DO, SRT, temperature, and TAN concentrations varied. This leads to the conclusion that nitritation is performing well over a large operating window in the tested process configuration. This new nitritation method is advantageous because fluctuation in the influent, sensor inaccuracy, or accidental operational changes do not result in treatment failure (i.e., a switch to nitrification). Furthermore, and in contrast with other nitritation systems previously proposed, no sludge treatment with FA or FNA, starvation, or sulfide inhibition was required to suppress NOB growth in this study (Duan et al., 2019; Seuntjens et al., 2018). The reliability of the reactor operation reported here was further demonstrated by successfully replicating nitritation in a bench-scale reactor with different geometry than R1-PN for over 400 days (Fig. 4). Moreover, successful replication and upscalability of nitritation to an $8 \mathrm{~m}^{3}$ pilot-scale reactor (R3-PN) was demonstrated (Fig. 5). In R3-PN, the TAN in the influent and effluent averaged $20 \pm 8 \mathrm{mgNH}_{4}-\mathrm{N} / \mathrm{L}$ and $7 \pm 1.8$ $\mathrm{mgNH}_{4}-\mathrm{N} / \mathrm{L}$, respectively. Wastewater temperatures as low as $8{ }^{\circ} \mathrm{C}$ were measured during winter. However, no increase in NOB activity was ever recorded, demonstrating that nitritation is achievable even at effluent ammonium concentrations below $10 \mathrm{mgNH}_{4}-\mathrm{N} / \mathrm{L}$ and low temperatures.

Apart from achieving high nitritation efficiency (i.e., very little nitrate production), reactors must operate at ammonium loading rates competitive with existing nitrification plants $\left(50-300 \mathrm{mgNH}_{4}-\mathrm{N} / \mathrm{L} / \mathrm{d}\right.$ ), depending on the wastewater temperature, TKN load, and target mixed liquid suspended solids concentration (Metcalf et al., 2013). At bench-scale, the maximum AOB activity measured was $3000 \mathrm{mgNH}_{4}-\mathrm{N} / \mathrm{L} / \mathrm{d}$ when sludge was retained via a sieve (SI, Fig. S14), whereas the ammonium loading ranged from 100 to 450 $\mathrm{mgNH}_{4}-\mathrm{N} / \mathrm{L} / \mathrm{d}$ (SI, Fig. S15). AOB are only active during the aerated period of the SBR cycle (i.e., no ammonium is oxidized during sedimentation, reactor filling, and anaerobic stirring). This results in a significant difference between the loading rate and activity measurement. When ammonium loading rates reached $400 \mathrm{mgNH}_{4}-\mathrm{N} / \mathrm{L} / \mathrm{d}$ the reactor R1-PN became hydraulically limited (HRT $\approx 2.5 \mathrm{~h}$ ). However, the ammonium loading rates could be further increased in two ways: First, if the wastewater would contain more ammonium (e.g., if rainwater and sewage are not mixed), the overall SBR cycle would only slightly increase in length since the aeration phase was only a fraction of the total SBR cycle duration. Second, the ammonium loading rate could be increased if the reactor could be operated at a lower HRT, for example, by shortening the filling phase or reducing the length of the anaerobic phase.

\subsection{What is limiting the growth of NOB?}

Based on our experimental data (i.e., the high NR in R1-PN, R2-PN and R3-PN) it became evident that ammonium-oxidizing activity could be successfully enriched in a high-volume exchange bottom-fed SBR while only an

Table 3

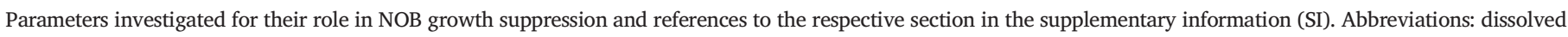

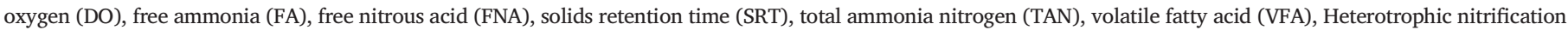
(HN), Ammonia-oxidizing archaea (AOA).

\begin{tabular}{|c|c|c|c|c|c|}
\hline Type of parameter & Parameters investigated (re & ence to SI) & & & \\
\hline Substrate Limitation & DO (SI, 3.1.1) & DO/TAN (SI, 3.1.2) & Alkalinity (SI, 3.1.3) & Phosphate (SI, 3.1.4) & Trace elements (SI, 3.1.5) \\
\hline Toxicity/inhibition & FA \& FNA (SI, 3.2.1) & $\mathrm{pH}(\mathrm{SI}, 3.2 .1)$ & Sulfide (SI, 3.2.2) & VFAs (SI, 3.2.3) & \\
\hline Lag-phase & Anaerobic time (SI, 3.3.1) & & & & \\
\hline Miscellaneous & Redox (SI, 3.4.1) & SRT (SI, 3.4.2) & Ammonium residual (SI, 3.4.3) & HN, AOA, Comammox (SI, 3.4.4) & \\
\hline
\end{tabular}


insignificant NOB population persisted in the sludge (SI, Fig. S16). However, when the NOB were supplied with oxygen and nitrite, they multiplied exponentially with $\mu=0.58 \mathrm{~d}^{-1}$ in the wastewater matrix (Fig. 6). This growth rate is similar to published values (Munz et al., 2011). It is thus unlikely that a persistent, toxic compound inhibited NOB growth or that a trace element limitation of the influent prevented NOB growth. The calculated SRT $\mathrm{aer}_{\text {,min }}$ for NOB was $2 \mathrm{~d}$, significantly lower than the actual SRT $\mathrm{aer}_{\text {in }}$ R1-PN of 8-20 d (between days 346-481). Numerous experiments and addition analyses were performed (as listed in Table 3 ) to identify the parameter(s) that may explain the observed four- to tenfold reduction in the NOB growth rates. Yet, none of the investigated parameters was ostensibly responsible (SI, Section 3).

Therefore, we shifted our focus to test whether the calculation of an $\mathrm{SRT}_{\mathrm{aer}}$ of 8-20 d was based on valid assumptions, namely the premise that the sludge wasted or lost in the effluent was representative of the sludge in the reactor. Bacterial species, which live as free cells, may be preferentially washed out of the reactor during the bottom-feed step and would not be retained by a sieve with a pore size of $50 \mu \mathrm{m}$. However, when the sieve's effectiveness in $\mathrm{AOB}$ and NOB retention was tested, it was found that the nitrifiers were retained even better than the average suspended solids, i.e., AOB and NOB activity per gTSS was lower in the filtrate than in the reactor and retained sludge (Fig. 7). This might be due to the tendency of AOB and NOB to form micro-colonies (Okabe et al., 1999). Such $\mathrm{AOB}$ and NOB micro-colonies were visualized with the fluorescent in-situ hybridization (FISH) method in the sludge of R1-PN in the "Tracing effluent AOB and NOB activity" experiment (SI, Fig. S10). Based on this result, the actual SRT of AOB and NOB should be even higher than the calculated SRT.

\subsection{NOB inactivation through an unknown mechanism}

The conducted experiments showed that bacterial washout cannot explain the decline in NOB activity at a high SRT (Fig. 8). There are a number of alternative mechanisms to explain the observed NOB inactivation. Many NOB species are metabolically versatile, and are capable to perform alternative (heterotrophic) metabolic activities (Boddicker and Mosier, 2018; Koch et al., 2015). An environmental stimulus (pH, redox, substrate concentrations, etc.) or competition may have induced such a metabolic switch in our setting, explaining the decrease in nitrite oxidation activity. Similarly, a change in the environmental conditions could have driven NOBs into a dormant state which would also have resulted in decreased NOB activity. Finally, if bacterial decay or inactivation is faster than growth (i.e., $\mu_{\mathrm{NOB}}<b_{\mathrm{NOB}}$ ) NOB activity would decline over time. $\mu_{\mathrm{NOB}}$ is affected by the concentration of substrates required for NOB growth (oxygen, nitrite, carbon dioxide, phosphate, trace elements). Many of these parameters were investigated in this study and could be excluded as growth-limiting constraints (inferred from NOB activity). The decay rate $\left(\mathrm{b}_{\mathrm{NOB}}\right)$ could also have been increased due to the presence of bactericidal compounds such as FNA, as a consequence of the infection of NOBs with bacteriophages or due to increased grazing of NOBs by protists. Yet, these factors were not tested in this study and should be the target of future work.

While it remains uncertain as to what exactly is responsible for the reduced NOB activity, we propose that the low NOB activity is due to a combination of washout and inactivation with the contribution of each mechanism depending on the SRT. During the "Tracing effluent AOB and NOB activity" experiment, the SRT ranged between 1.7 and $13.5 \mathrm{~d}$ and NOB activity declined by $77 \%$ within only 8 days (Fig. 7), i.e., washout dominated; during the "Sludge recirculation experiment" the SRT ranged between 28 and $59 \mathrm{~d}$ and NOB activity decreased by $74 \%$ within 22 days, i.e., decay dominated. Therefore, initially, a short SRT of $2-5 \mathrm{~d}$ can be applied to rapidly wash out NOB. Thereafter, the SRT can be increased to accumulate AOB biomass.

\subsection{Relative $A O B$ abundance decreases while high ammonium oxidation rates are maintained}

Intriguingly, microbial community analysis showed a decreasing trend for the AOB population over the course of the study period from $4 \%$ to $0.1 \%$ relative abundance on day 481 (Fig. 3A). After day 132 (implementation of the anaerobic phase), the NR stayed close to 1 (Fig. 2) and the ammonium oxidation rate remained stable or even increased (SI, Fig. S14), while the relative $\mathrm{AOB}$ abundance continuously decreased. If other bacterial species grew and accumulated in the reactor, the relative $\mathrm{AOB}$ abundance would have declined but the absolute AOB population would not have shrunk. However, based on the amount of organic substrate degraded, and the amount of ammonium oxidized, during each SBR cycle, the calculated relative abundance of AOB should be 5-15\% depending on the SRT (SI, Fig. S12C). It is unclear, which substrate would possibly have fostered the growth of a side-population so big that it could explain the discrepancy between the measured and theoretical relative abundance of AOBs. Special attention was paid to the period between days 347-481, when SRT increased from around 10 to 75 days (Fig. 2C) and TSS increased from 1 to 11 gTSS/L (Fig. 2B). Simultaneously, the maximum ammonium oxidation rate increased from $200 \mathrm{mgNH}_{4}-\mathrm{N} / \mathrm{L} / \mathrm{h}$ to $3000 \mathrm{mgNH}_{4}-\mathrm{N} / \mathrm{L} / \mathrm{h}$ (SI, Fig. S14). The increase in TSS should be largely due to the accumulation of inert matter and the AOB:Het ratio should even increase. Yet, the lowest relative AOB abundance (0.1\%) was measured on day 481. This lack of AOB was further confirmed by FISH staining (SI, Fig. S11). High amounts of non-active VSS could have influenced the DNA extraction, but no irregularities were detected in quality control data (e.g., the amount of DNA extracted, rarefaction curves, and reads). Alternatively, a population shift could have occurred towards heterotrophic nitrification (HN) or ammonium oxidizing archaea (AOA). A tenuous correlation between the decline of $\mathrm{AOB}$ in Fig. 3A and an increase in genera containing heterotrophic-nitrifier species seems to exist (SI, Fig. S13). Such a population shift might also be responsible for the initial decrease in $\mathrm{r}_{\mathrm{AOB}}$ in R2-PN (Fig. 4B, no microbial community data available). Yet two experiments performed with sludge from R1PN (SI, Section 3.4.4) suggested that neither HN nor AOA contributed significantly to ammonium oxidation. The possibility of an unknown bacterial or archaeal taxon contributing to ammonium-oxidation activity therefore has to be taken into account. The absence of known ammonium oxidizers will require further investigation, but was outside the scope of this manuscript.

\subsection{Limitations}

\subsubsection{Lack of mechanistic understanding of NOB suppression}

Combining the nitritation system reported here with an anammox reactor for efficient and robust mainstream nitrogen removal still requires a detailed understanding of the NOB suppression mechanisms. Our efforts in this direction did not identify a clear dominant factor thus additional work is needed. Some experiments conducted during this study were only performed as batch experiments; future work should include experiments with continuous cultures (e.g., to study the long-term influence of intermittent exposure to sulfide or VFAs). A major step forward would be the ability to determine whether the loss of NOB activity is caused by an increase of decay $\left(b_{\mathrm{NOB}}\right)$ or a decrease of growth $\left(\mu_{\mathrm{NOB}}\right)$ (both cases would result in the situation observed in Fig. 8, where $b_{\mathrm{NOB}}>\mu_{\mathrm{NOB}}$ ). Finally, in this study, each parameter tested alone did not have a significant impact on NOB activity, but multiple parameters together could well have a synergistic negative effect on NOB activity, as also observed in Seuntjens et al. (2018).

Moreover, inhibition thresholds for FNA, much lower than typically observed in Nitrobacter, have been reported by Vadivelu et al. (2006). In their experiments, the nitrite uptake rate (NUR) decreased by only $24 \%$ in the absence of $\mathrm{CO}_{2}$ (i.e., in the absence of NOB growth). This implies that the rate of substrate utilization depends on growth (i.e., anabolism) and maintenancedependent terms (Pirt, 1982). Vadivelu et al. (2006) showed that FNAinduced NOB anabolism inhibition begins already at $0.011 \mathrm{mgFNA}-\mathrm{N} / \mathrm{L}$ (significantly below reported inhibition constants for the metabolization of the primary substrate nitrite) and reaches $100 \%$ (i.e., complete cessation of growth) at $0.03 \mathrm{mgFNA}-\mathrm{N} / \mathrm{L}$. Note that such a mechanism changes the NOB substrate turnover very little (which in this study was used as an approximation for growth inhibition) but drastically increases the required $\mathrm{SRT}_{\text {aer }}$. As discussed in Section 3.2, FNA concentration did not exceed 0.012 mgFNA/L, in our nitritation reactors, so that significant growth inhibition can be excluded. Yet other, similar, unidentified mechanisms cannot be excluded a priori. 


\subsubsection{Operational complexity}

The reactor operation reported here (i.e., sedimentation, bottom-feed, anaerobic mixing, and constant aeration) achieved near-complete NOB suppression over a year and has been replicated in three reactors. However, under real-world conditions, additional levels of complexity should be tackled. For example, to reach the $\mathrm{NH}_{4}^{+}: \mathrm{NO}_{2}^{-}$ratio required for subsequent treatment in an anammox reactor, an algorithm needs to be implemented which calculates an appropriate $\mathrm{NH}_{4}$ end-concentration, for each SBR cycle (see Section 2.2, R3-PN). Then, to transfer wastewater with a specific $\mathrm{NH}_{4}^{+}: \mathrm{NO}_{2}^{-}$ratio to a subsequent anammox reactor, an efficient plug flow feeding step is needed, in which the new and old wastewater mix as little as possible. Alternatively, if nitritation was stable down to very low ammonium concentrations, near-complete oxidation of ammonium to nitrite could be targeted. In the anammox reactor the nitrite-rich effluent from the nitritation reactor would then be combined with ammonium-rich effluent from the carbon removal stage to allow for anammox-based nitrogen removal. The design could be simplified if the system worked as a single-stage PNA, where, after achieving an appropriate $\mathrm{NH}_{4}^{+}: \mathrm{NO}_{2}^{-}$ratio, aeration would be switched off and anoxic nitrogen removal could be performed. However, before further investigating, and finally stipulating the most viable process design for efficient PNA, a more detailed understanding of NOB suppression is of paramount importance.

\section{Conclusions}

- A simple SBR operation procedure with only four steps allowed for successful nitritation in municipal wastewater. The introduction of an anaerobic phase was key to stable nitritation.

- The SBR operation procedure can be implemented into reactors with differing geometries and different scales (i.e., 12-8000 L), demonstrating broad applicability.

- High nitritation efficiency can be maintained at low temperatures $\left(<15^{\circ} \mathrm{C}\right)$ and at variable municipal wastewater compositions.

- Nitritation is achieved through NOB inactivation, and parameters (DO, FA, FNA, lag-phase, redox conditions, DO/TAN ratio, $\mathrm{pH}$, sulfide concentration, SRT, phosphate limitation, trace element limitation, VFAs) potentially responsible for the inactivation were investigated. None of these could, by themselves, explain NOB inactivation.

This study has identified a new, reliable and scalable operational approach to establish nitritation in mainstream wastewater. However, a detailed understanding of NOB inactivation is still missing. Resolving the inactivation mechanism will be a critical step forward in ongoing efforts to successfully engineer and improve mainstream PNA-based wastewater treatment systems.

\section{CrediT authorship contribution statement}

Damian Hausherr: Conceptualization, Methodology, Investigation, Data Curation, Writing - Original Draft, Visualization. Robert Niederdorfer: Conceptualization, Methodology, Writing - Review \& Editing. Helmut Bürgmann: Conceptualization, Writing - Review \& Editing, Funding acquisition. Moritz Lehmann: Conceptualization, Writing - Review \& Editing, Funding acquisition. Paul Magyar: Conceptualization, Writing - Review \& Editing. Joachim Mohn: Conceptualization, Writing - Review \& Editing, Funding acquisition. Eberhard Morgenroth: Conceptualization, Writing Review \& Editing, Supervision. Adriano Joss: Conceptualization, Writing Review \& Editing, Supervision, Funding acquisition.

\section{Declaration of competing interest}

The authors declare that they have no known competing financial interests or personal relationships that could have appeared to influence the work reported in this paper.

\section{Acknowledgements}

This study was funded by the Swiss National Science Foundation through the IsoMol project, grant number 170876. We thank Marco Kipf and Richard Fankhauser for technical support in the experimental setup and Karin Rottermann, Sylvia Richter, Jacqueline Traber and Brian Sinnet for assisting in analytical methods. We also thank Laura Orschler and Shelesh Agrawal for their valuable input and discussions regarding the microbial community composition.

The graphical abstract was made with elements from flaticon.com. Black arrow (icon name: "Share", Style: Basic straight lineal).

\section{Data availability}

Data used for this study is available at the Eawag Research Data Institutional Collection (ERIC) at https://doi.org/10.25678/00053F.

\section{Appendix A. Supplementary data}

Supplementary data to this article can be found online at https://doi. org/10.1016/j.scitotenv.2022.153546.

\section{References}

Agrawal, S., Seuntjens, D., Cocker, P.De, Lackner, S., Vlaeminck, S.E., 2018. Success of mainstream partial nitritation/anammox demands integration of engineering, microbiome and modeling insights. Curr. Opin. Biotechnol. 50, 214-221. https://doi.org/10.1016/j. copbio.2018.01.013.

Albertsen, M., Karst, S.M., Ziegler, A.S., Kirkegaard, R.H., Nielsen, P.H., 2015. Back to basics the influence of DNA extraction and primer choice on phylogenetic analysis of activated sludge communities. PLoS One 10, e0132783. https://doi.org/10.1371/journal.pone. 0132783.

An, Z., Kent, T.R., Sun, Y., Bott, C.B., Wang, Z., 2021. Free ammonia resistance of nitriteoxidizing bacteria developed in aerobic granular sludge cultivated in continuous upflow airlift reactors performing partial nitritation. Water Environ. Res. 93, 421-432. https:// doi.org/10.1002/wer.1440.

Anthonisen, A.C., Loehr, R.C., Prakasam, T.B.S., Srinath, E.G., 1976. Inhibition of nitrification by ammonia and nitrous acid. J. Water Pollut. Control Fed. 48, 835-852. https://www. jstor.org/stable/2503897.

APHA, AWWA, WEF, 2012. Standard methods for the examination of water and waste water. American Public Health Association.

Bartrolí, A., Pérez, J., Carrera, J., 2010. Applying ratio control in a continuous granular reactor to achieve full nitritation under stable operating conditions. Environ. Sci. Technol. 44, 8930-8935. https://doi.org/10.1021/es1019405.

Blackburne, R., Vadivelu, V.M., Yuan, Z., Keller, J., 2007. Determination of growth rate and yield of nitrifying bacteria by measuring carbon dioxide uptake rate. Water Environ. Res. 79, 2437-2445. https://doi.org/10.2175/106143007X212139.

Boddicker, A.M., Mosier, A.C., 2018. Genomic profiling of four cultivated Candidatus nitrotoga spp. predicts broad metabolic potential and environmental distribution. ISME J. 12, 2864-2882. https://doi.org/10.1038/s41396-018-0240-8.

Brotto, A.C., Li, H., Dumit, M., Gabarró, J., Colprim, J., Murthy, S., Chandran, K., 2015. Characterization and mitigation of nitrous oxide ( $\mathrm{N}_{2} \mathrm{O}$ ) emissions from partial and fullnitrification BNR processes based on post-anoxic aeration control. Biotechnol. Bioeng. 112, 2241-2247. https://doi.org/10.1002/bit.25635.

Cao, Y., van Loosdrecht, M.C.M., Daigger, G.T., 2017. Mainstream partial nitritationanammox in municipal wastewater treatment: status, bottlenecks, and further studies. Appl. Microbiol. Biotechnol. 101, 1365-1383. https://doi.org/10.1007/s00253-0168058-7.

Duan, H., Ye, L., Lu, X., Yuan, Z., 2019. Overcoming nitrite oxidizing bacteria adaptation through alternating sludge treatment with free nitrous acid and free ammonia. Environ. Sci. Technol. 53, 1937-1946. https://doi.org/10.1021/acs.est. 8b06148.

Feng, Y., Peng, Y., Wang, B., Liu, B., Li, X., 2021. A continuous plug-flow anaerobic/aerobic/ anoxic/aerobic (AOAO) process treating low COD/TIN domestic sewage: realization of partial nitrification and extremely advanced nitrogen removal. Sci. Total Environ. 771, 145387. https://doi.org/10.1016/j.scitotenv.2021.145387.

Gilbert, E.M., Agrawal, S., Brunner, F., Schwartz, T., Horn, H., Lackner, S., 2014. Response of different nitrospira species to anoxic periods depends on operational DO. Environ. Sci. Technol. 48, 2934-2941. https://doi.org/10.1021/es404992g.

Hellinga, C., Schellen, A.A.J.C., Mulder, J.W., Van Loosdrecht, M.C.M., Heijnen, J.J., 1998. The SHARON process: an innovative method for nitrogen removal from ammonium-rich waste water. Water Sci. Technol. https://doi.org/10.1016/S02731223(98)00281-9.

Illumina, I., 2015. 16S metagenomic sequencing library preparation, part \# 15044223. Rev. B.

Isanta, E., Reino, C., Carrera, J., Pérez, J., 2015. Stable partial nitritation for low-strength wastewater at low temperature in an aerobic granular reactor. Water Res. 80, 149-158. https://doi.org/10.1016/j.watres.2015.04.028. 
Jemaat, Z., Bartrolí, A., Isanta, E., Carrera, J., Suárez-Ojeda, M.E., Pérez, J., 2013. Closed-loop control of ammonium concentration in nitritation: convenient for reactor operation but also for modeling. Bioresour. Technol. 128, 655-663. https://doi.org/10.1016/j. biortech.2012.10.045.

Kent, T.R., Sun, Y., An, Z., Bott, C.B., Wang, Z., 2019. Mechanistic understanding of the NOB suppression by free ammonia inhibition in continuous flow aerobic granulation bioreactors. Environ. Int. 131, 105005. https://doi.org/10.1016/j.envint.2019.105005.

Koch, H., Lücker, S., Albertsen, M., Kitzinger, K., Herbold, C., Spieck, E., Nielsen, P.H., Wagner, M., Daims, H., 2015. Expanded metabolic versatility of ubiquitous nitriteoxidizing bacteria from the genus nitrospira. Proc. Natl. Acad. Sci. 112, 11371-11376. https://doi.org/10.1073/pnas.1506533112.

Kosgey, K., Chandran, K., Gokal, J., Kiambi, S.L., Bux, F., Kumari, S., 2021. Critical analysis of biomass retention strategies in mainstream and sidestream ANAMMOX-mediated nitrogen removal systems. Environ. Sci. Technol. 55, 9-24. https://doi.org/10.1021/acs.est. 0c00276.

Laloo, A.E., Wei, J., Wang, D., Narayanasamy, S., Vanwonterghem, I., Waite, D., Steen, J., Kaysen, A., Heintz-Buschart, A., Wang, Q., Schulz, B., Nouwens, A., Wilmes, P., Hugenholtz, P., Yuan, Z., Bond, P.L., 2018. Mechanisms of persistence of the ammoniaoxidizing bacteria nitrosomonas to the biocide free nitrous acid. Environ. Sci. Technol. 52, 5386-5397. https://doi.org/10.1021/acs.est.7b04273.

Laureni, M., Weissbrodt, D.G., Villez, K., Robin, O., de Jonge, N., Rosenthal, A., Wells, G., Nielsen, J.L., Morgenroth, E., Joss, A., 2019. Biomass segregation between biofilm and flocs improves the control of nitrite-oxidizing bacteria in mainstream partial nitritation and anammox processes. Water Res. 154, 104-116. https://doi.org/10.1016/j.watres. 2018.12.051.

Layer, M., Adler, A., Reynaert, E., Hernandez, A., Pagni, M., Morgenroth, E., Holliger, C., Derlon, N., 2019. Organic substrate diffusibility governs microbial community composition, nutrient removal performance and kinetics of granulation of aerobic granular sludge. Water Res. X 4, 100033. https://doi.org/10.1016/j.wroa.2019.100033.

Li, X., Klaus, S., Bott, C., He, Z., 2018. Status, challenges, and perspectives of mainstream nitritation-anammox for wastewater treatment. Water Environ. Res. 90, 634-649. https://doi.org/10.2175/106143017X15131012153112.

Liu, G., Wang, J., 2013. Long-term low DO enriches and shifts nitrifier community in activated sludge. Environ. Sci. Technol. 47, 5109-5117. https://doi.org/10.1021/es304647y.

Liu, J., Zhang, L., Qiu, S., He, Q., Zhang, Q., Peng, Yongzhen, Peng, Yi, 2021. Insight into the mechanism of nitritation establishment through external fermented sludge addition. Bioresour. Technol. 341, 125763. https://doi.org/10.1016/j.biortech.2021.125763.

Manser, R., Gujer, W., Siegrist, H., 2005. Consequences of mass transfer effects on the kinetics of nitrifiers. Water Res. 39, 4633-4642. https://doi.org/10.1016/j.watres. 2005.09.020.

McCarty, P.L., 2018. What is the best biological process for nitrogen removal: when and why? Environ. Sci. Technol. 52, 3835-3841. https://doi.org/10.1021/acs.est. 7 b05832.

Metcalf, Eddy, I., Burton, F.L., Tchobanoglous, G., Tsuchihashi, R., Stensel, H.D., 2013. Wastewater Engineering : Treatment and Resource Recovery. Fifth. ed. McGraw-Hill Education.

Munz, G., Lubello, C., Oleszkiewicz, J.A., 2011. Factors affecting the growth rates of ammonium and nitrite oxidizing bacteria. Chemosphere 83, 720-725. https://doi.org/10. 1016/j.chemosphere.2011.01.058.

Okabe, S., Satoh, H., Watanabe, Y., 1999. In situ analysis of nitrifying biofilms as determined by in situ hybridization and the use of microelectrodes. Appl. Environ. Microbiol. 65, 3182-3191. https://doi.org/10.1128/AEM.65.7.3182-3191.1999.
Park, S., Bae, W., 2009. Modeling kinetics of ammonium oxidation and nitrite oxidation under simultaneous inhibition by free ammonia and free nitrous acid. Process Biochem. 44, 631-640. https://doi.org/10.1016/j.procbio.2009.02.002.

Pirt, S.J., 1982. Maintenance energy: a general model for energy-limited and energy-sufficient growth. Arch. Microbiol. 133, 300-302. https://doi.org/10.1007/BF00521294.

Poot, V., Hoekstra, M., Geleijnse, M.A.A., van Loosdrecht, M.C.M., Pérez, J., 2016. Effects of the residual ammonium concentration on NOB repression during partial nitritation with granular sludge. Water Res. 106, 518-530. https://doi.org/10.1016/j.watres. 2016.10.028.

Regmi, P., Miller, M.W., Holgate, B., Bunce, R., Park, H., Chandran, K., Wett, B., Murthy, S., Bott, C.B., 2014. Control of aeration, aerobic SRT and COD input for mainstream nitritation/denitritation. Water Res. 57, 162-171. https://doi.org/10.1016/j.watres. 2014.03.035.

Reino, C., Suárez-Ojeda, M.E., Pérez, J., Carrera, J., 2016. Kinetic and microbiological characterization of aerobic granules performing partial nitritation of a low-strength wastewater at $10{ }^{\circ} \mathrm{C}$. Water Res. 101, 147-156. https://doi.org/10.1016/j.watres.2016.05.059.

Seuntjens, D., Van Tendeloo, M., Chatzigiannidou, I., Carvajal-Arroyo, J.M., Vandendriessche, S., Vlaeminck, S.E., Boon, N., 2018. Synergistic exposure of return-sludge to anaerobic starvation, sulfide, and free ammonia to suppress nitrite oxidizing bacteria. Environ. Sci. Technol. 52, 8725-8732. https://doi.org/10.1021/acs.est.7b06591.

Sui, Q., Jiang, L., Di, F., Yue, W., Chen, Y., Wang, H., Chen, M., Wei, Y., 2020. Multiple strategies for maintaining stable partial nitritation of low-strength ammonia wastewater. Sci. Total Environ. 742, 140542. https://doi.org/10.1016/j.scitotenv.2020.140542.

Third, K.A., Sliekers, A.O., Kuenen, J.G., Jetten, M.S.M., 2001. The CANON system (Completely autotrophic nitrogen-removal over nitrite) under ammonium limitation: interaction and competition between three groups of bacteria. Syst. Appl. Microbiol. 24, 588-596. https://doi.org/10.1078/0723-2020-00077.

Vadivelu, V.M., Yuan, Z., Fux, C., Keller, J., 2006. The inhibitory effects of free nitrous acid on the energy generation and growth processes of an enriched nitrobacter culture. Environ. Sci. Technol. 40, 4442-4448. https://doi.org/10.1021/es051694k.

Wang, J., Song, J., Yin, F., Shen, Y., Yang, D., Liu, W., 2021. Insight into how high dissolved oxygen favors the startup of nitritation with aerobic granules. Chemosphere 270, 128643. https://doi.org/10.1016/j.chemosphere.2020.128643.

Wiesmann, U., 1994. Biological nitrogen removal from wastewater. Biotechnics/Wastewater. Springer, Berlin Heidelberg, Berlin, Heidelberg, pp. 113-154 https://doi.org/10.1007/ BFb0008736.

Wijffels, R.H., de Gooijer, C.D., Kortekaas, S., Tramper, J., 1991. Growth and substrate consumption ofNitrobacter agilis cells immobilized in carrageenan: part 2Model evaluation. Biotechnol. Bioeng. 38, 232-240. https://doi.org/10.1002/bit.260380304.

Wong-Chong, G., Loehr, R., 1978. Kinetics of microbial nitrification: nitrite-nitrogen oxidation. Water Res. 12, 605-609. https://doi.org/10.1016/0043-1354(78)90140-9.

Xiao, H., Peng, Y., Zhang, Q., Liu, Y., 2021. Pre-anaerobic treatment enhanced partial nitrification start-up coupled with anammox for advanced nitrogen removal from low $\mathrm{C} / \mathrm{N}$ domestic wastewater. Bioresour. Technol. 337, 125434. https://doi.org/10.1016/j. biortech.2021.125434.

Zhang, L., Yang, J., Furukawa, K., 2010. Stable and high-rate nitrogen removal from reject water by partial nitrification and subsequent anammox. J. Biosci. Bioeng. 110, 441-448. https://doi.org/10.1016/j.jbiosc.2010.05.008.

Zheng, M., Wang, Z., Meng, J., Hu, Z., Liu, Y., Yuan, Z., Hu, S., 2021. Inactivation kinetics of nitrite-oxidizing bacteria by free nitrous acid. Sci. Total Environ. 752, 141876. https:// doi.org/10.1016/j.scitotenv.2020.141876. 